\section{Oil exploitation in the Amazon basin of Ecuador: a public health emergency}

\author{
Miguel San Sebastián ${ }^{1}$ and \\ Anna-Karin Hurtig ${ }^{1}$
}

Oil is a major source of income for Ecuador and since the 1970s has been the "engine" of the nation's economy. Before the 1970s oil price boom, Ecuador was one of the poorest countries in Latin America. Since then, oil production has been the primary cause of Ecuador's economic growth, which has averaged 7\% annually. Per capita income rose from US\$ 290 in 1972 to US\$ 1200 in 2000. Today, oil continues to account for $40 \%$ of the nation's export earnings and of the budget of the national Government $(1,2)$. Most of this oil comes from the northeastern part of the country, the Amazon basin.

The Amazon basin of Ecuador, known as el Oriente (the provinces of Sucumbios, Orellana, Napo, Pastaza, Morona Santiago, and ZamoraChinchipe), consists of more than $100000 \mathrm{~km}^{2}$ of tropical rain forest lying at the headwaters of the Amazon river network. The region contains one of the most diverse collections of plant and animal life in the world (3). The Oriente region is also the home of some 500000 people, or about $4.5 \%$ of the country's population. These half-million persons include eight groups of indigenous people as well as peasants who, encouraged by land policies of the national Government, moved to the area from Ecuador's coastal and highland regions in the 1970s and the 1980s (4).

In 1967 a Texaco-Gulf consortium discovered a rich field of oil beneath the rain forest, leading to an oil boom that has permanently reshaped the region. The Amazon of Ecuador now houses a vast network of roads, pipelines, and oil facilities. While the national Government has retained dominion over all mineral rights, several private foreign companies have built and operated most of the oil infrastructure.

Current oil production activities in the Oriente region span nearly one million hectares, with over 300 producing wells and 29 production camps. The country has 4.6 billion barrels of proven oil reserves, with crude production of around 390000 barrels per day. Of this production, Petroecuador, the Government-owned company, accounts for about $55 \%$ of Ecuador's total output, with private companies accounting for the remaining $45 \%$. Petroecuador is attempting both to attract foreign investment to the country's largest oil fields and to boost its own production from around 215000 barrels per day today to 600000 barrels per day by 2005 (5).

Since 1967 many different companies have been involved in the oil exploitation process. There are currently 16 companies operating in the coun- 
try: Petroecuador, 3 private Ecuadorian companies, and 12 foreign companies (6). Figure 1 shows the oil companies now operating in the country and the blocks where they are located.

Since the beginning of oil exploitation, foreign oil companies and Petroecuador have extracted more than two billion barrels of crude oil from the Ecuadorian Amazon. However, in this development process, billions of gallons ( 1 gallon $=3.7853$ liters) of untreated wastes, gas, and crude oil have been released into the environment (7).

This paper examines the environmental and health impacts brought about by the oil development process in the Amazon region of Ecuador.

\section{THE ENVIRONMENTAL EXPOSURE}

\section{Source and extent of pollution}

Oil development activities include several contaminating processes. The extent of these polluting processes depends mainly on the environmental practices and technology used by oil companies. In Ecuador these practices have repeatedly been questioned (8-10).

Deep below the earth's surface, oil is usually mixed with natural gas and "formation water," which contains hydrocarbons, heavy metals, and a high concentration of salts. In the Amazon basin of

FIGURE 1. Oil blocks operated by oil companies, Ecuador, 2003

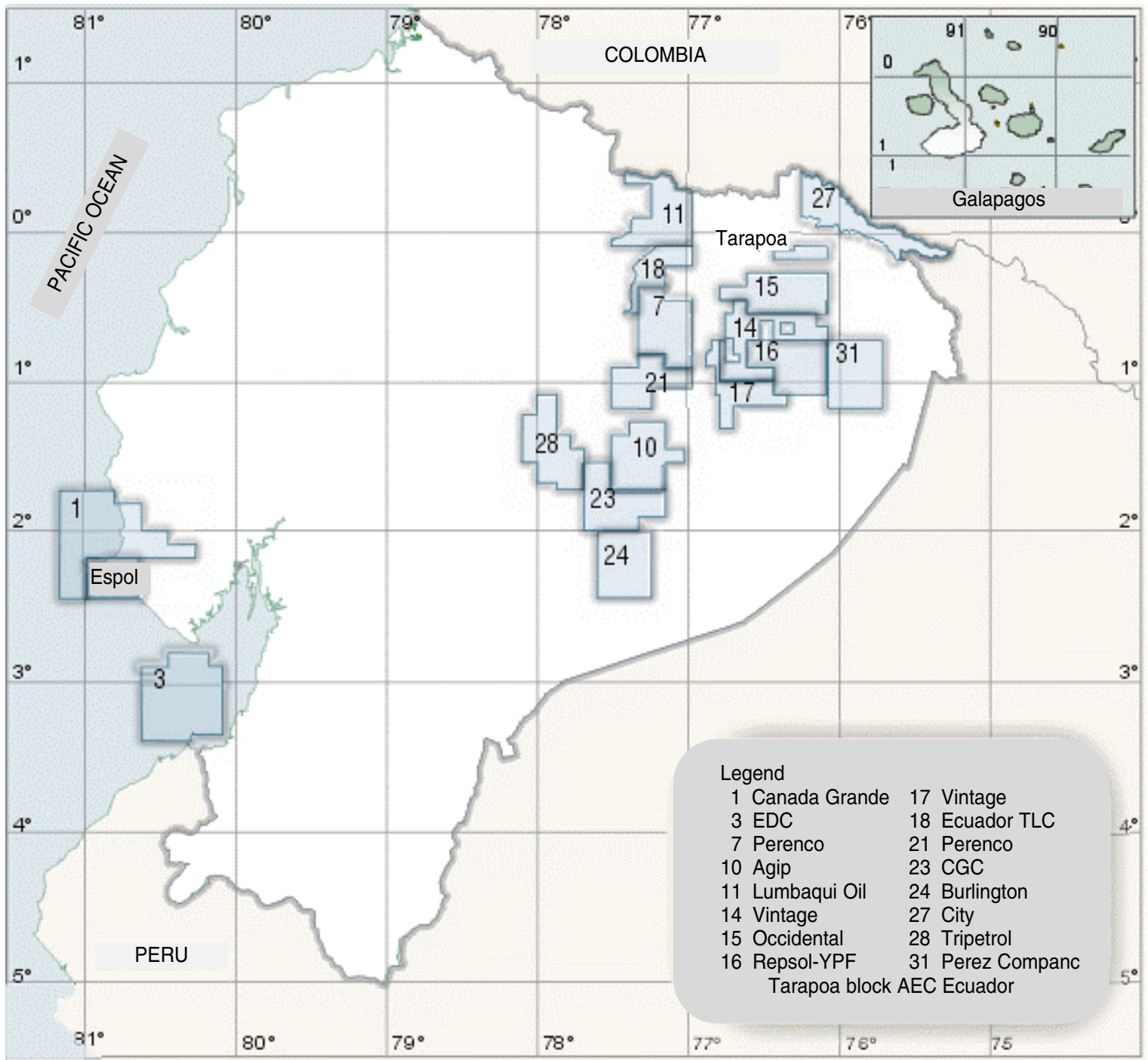

Source: Petroecuador (http://petroecuador.com.ec/donde.htm). Used with permission. 
Ecuador, each exploratory well that is drilled produces an average of 4000 cubic meters of drilling wastes, including formation water and drilling muds (which are used as lubricants and sealants). These wastes were frequently deposited into open, unlined pits called separation ponds, from which they were either directly discharged into the environment or they leached out as the pits degraded or overflowed from rainwater $(7,8)$. Although some companies have modified this practice in the last 10 years by building protected ponds, these practices still occur. There are currently nearly 200 open ponds in the Amazon region (11).

If commercial quantities of oil are found, the production stage starts. During production, oil is extracted in a mixture with formation water and gas and then separated in a central facility. At each facility, over 4.3 million gallons (16.3 million liters) of liquid wastes are generated every day and discharged without treatment into pits. Roughly 53 million cubic feet (1.5 million cubic meters) of "waste" gas from the separation process is burned daily without temperature or emissions controls. Air contamination can also be generated at pits and oil spills by hydrocarbons coming from standing oil slicks $(1,7)$.

Routine maintenance activities at over 300 producing wells discharge an estimated five million gallons (18.9 million liters) of untreated toxic wastes into the environment every year. Leaks from wells and spills from tanks have been common (12). According to a study conducted by the Government of Ecuador in 1989, spills from the flowlines that connect the wells to the stations were dumping an estimated 20000 gallons (75 800 liters) of oil every two weeks (13).

Spills from the main and secondary pipelines, which connect the separation stations to the refinery in the coastal region, are also common. In 1992 the Ecuadorian Government recorded approximately 30 major spills, with an estimated loss of 16.8 million gallons (63.6 million liters) of crude oil (7). In 1989 a spill of at least 294000 gallons (1.1 million liters) of crude oil caused the Napo River, which has a width of one $\mathrm{km}$, to run black for a week; the same thing happened in 1992, when there was a spill of about 275000 gallons (1.0 million liters) of crude oil (12). It was estimated in 2002 that two big spills per week were occurring from the main oil fields in the Oriente region (14).

Overall, during the period of 1972 through 1993, more than 30 billion gallons (114 billion liters) of toxic wastes and crude oil were discharged into the land and waterways of the Oriente (7). This compares to the 10.8 million gallons (40.9 million liters) spilled in the Exxon Valdez tanker disaster in 1989 in Alaska, one of the largest sea oil spills that has ever occurred.

\section{Environmental analysis}

Numerous reports have indicated that the contamination has occurred since the beginning of the oil exploration in the Ecuadorian Amazon (8$10,15)$ even though longitudinal data on the levels of population exposure over time do not exist.

A study in 1987 by the Ecuadorian Government found elevated levels of oil and grease in all of the 36 samples taken from rivers and streams near productions sites. That study also found that a shortage of dissolved oxygen in the majority of water samples had seriously harmed the aquatic ecosystem (16). In 1989 another Ecuadorian Government study of 187 wells found that crude oil was regularly dumped into the forests and into bodies of water (13).

In 1994 a study carried out by the Ecuadorian environmental and human rights organization Centro de Derechos Económicos y Sociales (the Center for Economic and Social Rights) also found highly elevated levels of oil pollutants in the streams and rivers of the Oriente area. Concentrations of polynuclear aromatic hydrocarbons were 10 to 10000 times greater than the levels recommended by the Environmental Protection Agency of the United States of America (9).

In 1998 an independent local laboratory that is frequently used by the oil companies surveyed 46 streams in the Oriente region (17). The laboratory found contamination by total petroleum hydrocarbons (TPH) in areas of oil activities, while no water contamination was found in areas without such activities.

In 1999 the Instituto de Epidemiología y Salud Comunitaria "Manuel Amunárriz" ("Manuel Amunárriz" Institute of Epidemiology and Community Health), a local nongovernmental organization concerned with health issues, undertook water analyses for TPH in communities near oil fields and also in communities far away from the fields. Those analyses showed high levels of TPH concentrations in rivers used by the communities that were close to the oil fields. In some streams, hydrocarbon concentrations exceeded by more than 100 times the limit permitted by European Community regulation (18).

Since 1999 the oil companies have been required by law to regularly monitor the level of pollution in the environment and to send reports to the national Government of Ecuador. This information is not open for public scrutiny. However, in 1999, when one of these reports was presented to a community that had made several complaints to the Ministry of Environment, it showed that streams in the community had concentrations of TPH that were over 500 times the limit permitted by European Community regulations (19). Nevertheless, the oil company and a representative of the Ecua- 
dorian Government insisted that the levels that had been found were acceptable.

For the Amazon basin of Ecuador, there is a lack of data on soil pollution and its possible impact, and no study has been conducted on the impact that oil development has had on fish and fishing. However, studies from the Amazon basin of Peru found, after an oil spill in the Marañon River, high concentrations of TPH in the stomach and muscles of fish (20).

\section{THE HEALTH EFFECTS}

Several studies have focused on residents exposed to major coastal oil spills from tankers (2123). However, there are few epidemiological studies concerning persons who live in communities that are near oil fields and who are exposed to acute and/or long-term contamination (24).

For many years residents of the oil-producing areas of the Ecuadorian Amazon have raised concerns over pollution related to oil development. Both peasants and indigenous people have reported that many local streams and rivers, once rich in fish, now support little or no aquatic life; further, cattle are reported to be dying from drinking from contaminated streams and rivers. These are typically the same waters that people use for drinking, cooking, and bathing. Residents have also reported that bathing in the river waters causes skin rashes, especially after heavy rains, which accelerate the flow of wastes from nearby pits into the streams (25).

In 1993 a community health workers association in the Ecuadorian Amazon conducted a descriptive study in its communities. The study suggested that, compared to communities free from oil exploitation, communities in oil-producing areas had elevated morbidity rates, with a higher occurrence of abortion, dermatitis, skin mycosis, and malnutrition, as well as higher mortality rates (26).

In 1994 the Center for Economic and Social Rights released a study reporting skin problems (dermatosis) in the population in the Ecuadorian Amazon, apparently related to crude oil contamination of local rivers (9).

In recent years the "Manuel Amunárriz" Institute of Epidemiology and Community Health has been involved in a research process to assess the potential health impact of oil pollution in communities near oil fields. In the first of these studies, women living in communities near oil fields reported higher rates of various physical symptoms than did women in control areas. These symptoms included skin mycosis, tiredness, itchy nose, sore throat, headache, red eyes, ear pain, diarrhea, and gastritis. After adjustment for possible confounding factors, the symptoms significantly associated with exposure were those expected from known toxicological ef- fects of oil (27). Another study found that the risk of spontaneous abortions was 2.5 times as high in women living in the proximity of oil fields (28).

Research done in 1998 found an excess of cancers among males in a village located in an oilproducing area in the Oriente region (29). Another study, from 2000, examined the differences in cancer incidences over the period of 1985 to 1998 in the Amazon region of Ecuador. This study found a significantly higher overall incidence of cancer in both men and women in the cantones ("counties," or divisions of provinces) where oil exploitation had been going on for at least 20 years. Significantly elevated levels were observed for cancers of the stomach, rectum, skin melanoma, soft tissue, and kidney in men and for cancers of the cervix and lymph nodes in women. An increase in hematopoietic cancers was observed in children (30).

\section{GOVERNMENT RESPONSES}

Peasants and indigenous people from the Amazon have presented their complaints to various administrations of the national Government of Ecuador. The inhabitants of the Ecuadorian Amazon have asked for a better quality of life and for technical assistance; that electricity, water, health services, and other basic services be provided; and, above all, that the oil pollution be remediated. Through their own organizations and with support from national environmental groups, Oriente residents have demanded that the companies clean up the environmental pollution and compensate them for damages caused by oil-related contamination. The measures adopted so far by oil companies and the various administrations of the national Government have been described as "patches," such as covering some waste pits, building some schools, and constructing roads, all without facing the root causes of the problem $(10,31,32)$.

Various administrations of the national Government of Ecuador have declared the essential importance of oil to Ecuador's development. However, despite the oil revenues, improvements in socioeconomic conditions in the country have fallen short of expectations. Ecuador now has the highest per capita debt of any country in South America, nearly US\$ 1100 per person (1). In the period from 1970 to 2002 the unemployment rate rose from $6.0 \%$ to $7.7 \%$, and the percentage of people living in poverty climbed from $47.0 \%$ to $61.3 \%(2,33)$. The ratio of the income received by the poorest $5 \%$ of the population and by the richest 5\% changed from 1:109 in 1988 to 1:206 in 1999 (34). The Amazon region has the worst infrastructure and the lowest socioeconomic and health indicators in the country (35).

In response to the nearly $\$ 16$ billion in external debt that Ecuador has, one of the main eco- 
nomic strategies of the national Government and the International Monetary Fund has been to expand the oil exploitation in the country. The national Government's proposals include opening two million hectares of pristine rain forest in the south of the Amazon to oil exploitation and constructing a new heavy crude oil pipeline in the north of the Amazon, to allow further oil exploitation in that area $(36,37)$.

\section{WHAT NEEDS TO BE DONE}

Modern oil and gas development, if compatible with sustainable development and the wellbeing of Amazonian peoples, must be based on comprehensive environmental planning that fully considers the cumulative impact of ongoing and planned oil exploitation throughout the region. Strict environmental controls and careful long-term monitoring of oil activities-with both of those firmly grounded in the rule of law and broad participation by local communities, local governments, and nongovernmental groups-are necessary in order to prevent further negative environmental and health impacts in the Oriente region (38). Five interrelated actions are urgently needed:

- The Ecuadorian Government should conduct an evaluation of the environmental situation in the Oriente region. It is also necessary to develop and oversee the implementation of a plan to repair the damage that has already occurred and to limit further destruction. While oil pollution persists, the health of the population of the Oriente area and other populations in similar situations will remain at risk. Some indigenous and environmental groups have called for the application of the precautionary principle. (The precautionary principle has been defined as "when an activity raises threats of harm to human health or the environment, precautionary measures should be taken even if some cause and effect relationships are not fully established scientifically" (39)). That principle has been developed by scientists in the face of scientific uncertainty, and it is a strong call for prevention of potential harm and for caution in actions taken. Those indigenous and environmental groups have also asked the national Government for a moratorium on oil and gas development in new areas of the Amazon. Such development alternatives as ecotourism and rain forest conservation have been proposed, and they should be seriously considered $(40,41)$.

- Oil companies operating in the Ecuadorian Amazon should change their practices to minimize environmental impacts and to build partnerships with local communities so that local residents benefit from development. Environmental protec- tion standards and environmental management plans should be accessible to and appropriately discussed with communities and independent environmental groups. Without such basic information, these groups are left unaware of potential risks, they cannot participate meaningfully in formulating public policy, and they cannot hold companies accountable for their actions. In addition, an environmental monitoring system should be established, with the involvement of the affected communities. As a minimum, this system should include regular detailed chemical sampling of the environment and reporting on the emissions and effluent controls.

- Oil development policies have an impact on health, and the consequences of those policies need to be assessed and taken into account. The Ecuadorian Government should acknowledge the need for health impact assessments as an integral feature of policy development and evaluation. Community consultation and participation are essential in assessing impacts on the environment and health (42).

- Ecuador enacted a new constitution in 1998. That document acknowledges the right of communities to be consulted by oil companies before the companies begin the exploratory stage of oil development. To enforce these rights, it is essential for community organizations to work with regional, national, and international environmental groups. The Ecuadorian Government has already given a commitment to develop mechanisms to enforce the laws protecting the environment and the health of their citizens, but developing those mechanisms will be difficult. This should be addressed within the context of promoting human rights, combating corruption, and strengthening democratic institutions.

- Concern has been raised around the world that globalization of trade does not bode well for the environment and for people's health (43-45). Shifting trade policies in the direction of environmental sustainability and social justice is urgently needed if environmental protection, economic security, and health benefits are to be received by the majority of the world's population.

We believe that oil exploitation in the Amazon basin of Ecuador has resulted in a public health emergency because of its adverse impact on the environment and health. So far, the Ecuadorian Government has not designed an adequate strategy to prevent further negative environmental and health impacts. The oil industry argues that it has a role to play in the development of the country (46-48), but that development should not come with the added cost of pollution and poor health.

At first, it may appear that the oil industry and public health are not related. However, we 
have shown that they are closely interconnected. Unfortunately, Ecuador is not the only country in Latin America to suffer the negative consequences of oil exploitation; Bolivia, Colombia, and Peru are in a similar situation $(49,50)$. There are already public health problems, and these problems may grow if unregulated oil exploitation continues to expand in Latin America. Preventing additional health and environmental damage will require action on a local, national, and international level.

Acknowledgments. The studies on the health impact of oil exploitation in Ecuador carried out by the "Manuel Amunárriz" Institute of Epidemiology and Community Health have been funded by the Vicariato de Aguarico (the local Catholic church) and Medicus Mundi Gipuzkoa (a Spanish nongovernmental organization).

Note on conflicts of interest. In 1993 a lawsuit was filed in the United States of America against Texaco, an oil company that had worked in Ecuador for more than 20 years. The plaintiffssome 30000 indigenous persons and peasantsclaimed that the oil company had caused irreparable damage to the rain forest of the Amazon region of Ecuador. In 2000 the suit was dismissed in the United States and sent to Ecuador to be considered. In October 2003 one of the authors, Miguel San Sebastián, presented testimony in an Ecuadorian court on behalf of the plaintiffs; he did not receive any payment for his testimony.

While the Revista Panamericana de Salud Pública/Pan American Journal of Public Health is affiliated with the Pan American Health Organization (PAHO), the Revista/Journal is an independent scientific publication whose articles do not necessarily reflect the opinions or official positions of PAHO or of its Member States on specific issues.

Note on alternative points of view. The $R e$ vista Panamericana de Salud Pública/Pan American Journal of Public Health welcomes letters to the editor that clarify, discuss, or comment in a constructive manner on ideas presented in the Revista/Journal. Letters should be signed by the author, should specify his or her professional affiliation and mailing address, and should list any potential conflicts of interest related to the subject of the letter. Letters are welcome in English, Spanish, or Portuguese. Letters can be sent via electronic mail to: publiper@ paho.org; letters can also be sent via postal mail to: Editor, Revista Panamericana de Salud Pública/Pan American Journal of Public Health, 525 Twenty-third Street, N.W., Washington, D.C. 20037, United States of America.

\section{SINOPSIS}

\section{La explotación petrolera en la cuenca amazónica de Ecuador: una emergencia para la salud pública}

Desde la década de 1970, el petróleo ha sido una de las principales fuentes de ingresos del Ecuador y ha servido como "motor impulsor" de la economía nacional. La mayor parte del petróleo ecuatoriano se extrae en la cuenca amazónica del nordeste del país. Desde que comenzó la explotación petrolera, compañias extranjeras y la empresa petrolera estatal Petroecuador han extraído más de dos mil millones de barriles de petróleo crudo de la Amazonía ecuatoriana. A lo largo de este proceso se han liberado al medio ambiente miles de millones de galones de desechos sin tratar, gas y petróleo crudo. Este artículo analiza el impacto ambiental y sanitario provocado por el desarrollo petrolero en la región amazónica del Ecuador. Por ejemplo, el análisis del agua de varias corrientes fluviales de la localidad ha demostrado la presencia de altas concentraciones de productos químicos derivados del petróleo en las zonas petroliferas en explotación. Los estudios epidemiológicos han encontrado un mayor riesgo de sufrir sintomas asociados con el petróleo y abortos espontáneos en las mujeres que viven en las proximidades de los campos petroleros. También se ha encontrado una incidencia excesiva de cáncer. Se necesitan intervenciones locales, nacionales e internacionales para evitar que se empeoren los efectos negativos que ejerce sobre el medio ambiente y la salud el desarrollo petrolero. Estas intervenciones deben abarcar un sistema de monitoreo y remediación ambiental, consultas a la comunidad y participación comunitaria, mecanismos para hacer cumplir las leyes que protegen el medio ambiente y la salud de la población, y cambios en las politicas comerciales dirigidos a lograr la sostenibilidad en materia ambiental y la justicia social.

\section{REFERENCES}

1. Centro de Derechos Económicos y Sociales. El petróleo no es eterno. Quito: Centro de Derechos Económicos y Sociales; 1999.

2. Instituto Latinoamericano de Investigaciones Sociales. Economía ecuatoriana en cifras, 1970-2003. Available from: http:/ / www.ildis.org.ec/estadisticas/ estadisticas.htm. Accessed 25 May 2003.

3. Ecuador rainforest. Available from: http://www.rainforestweb.org/ Rainforest_Regions/South_America/ Ecuador/?state=more. Accessed 25 May 2003.
4. Fundación José Peralta. Ecuador: su realidad. Quito: Fundación de Investigación y Promoción Social José Peralta; 2001.

5. United States of America, Environmental Information Agency. Ecuador: country analysis brief. Available from: 
http://www.eia.doe.gov/cabs/ecuador. html. Accessed 28 May 2003.

6. Petroecuador. Bloques concesionados. Available from: http://www.petroecuador. com.ec/donde.htm Accessed 28 May 2003.

7. Jochnick C, Normand R, Zaidi S. Rights violations in the Ecuadorian Amazon: the human consequences of oil development. Health Human Rights. 1994;1(1): 82-100.

8. Kimerling J. Amazon crude. New York: Brickfront Graphics Inc.; 1991.

9. Centro de Derechos Económicos y Sociales. Violaciones de derechos en la Amazonía Ecuatoriana. Quito: Abya-Yala; 1994.

10. Varea A, Ortiz P, eds. Marea negra en la Amazonía: conflictos socioambientales vinculados a la actividad petrolera en el Ecuador. Quito: Abya-Yala; 1995.

11. Frente de Defensa de la AmazoníaPetroecuador. Estudio para conocer el alcance de los efectos de la contaminación en los pozos y estaciones perforados antes de 1990 en los campos Lago Agrio, Dureno, Atacapi, Guanta, Shushufindi, Sacha, Yuca, Auca y Cononaco. Quito: Frente de Defensa de la Amazonía-Petroecuador; 2003.

12. Almeida A. Reseña sobre la historia ecológica de la Amazonía ecuatoriana. In: Martínez E, ed. El Ecuador post petrolero. Quito: Acción Ecológica; 2000. Pp. 27-38.

13. Dirección General de Medio Ambiente de Ecuador. Estudio de impacto ambiental 42. Quito: Dirección General de Medio Ambiente; 1989

14. 2 derrames de petróleo al mes en el campo Auca. El Comercio, 18 de octubre 2002.

15. Fabra A. Indigenous peoples, environmental degradation and human rights: a case study. In: Boyle A, Anderson M, eds. Human rights approaches to environmental protection. Oxford: Clarendon Press; 1998. Pp. 245-64.

16. Corporación Estatal Petrolera Ecuatoriana. Análisis de la contaminación ambiental en los campos petroleros Libertador y Bermejo. Quito: CEPE; 1987.

17. Zehner R, Villacreces LA. Estudio de la calidad de aguas de río en la zona de amortiguamiento del Parque Nacional Yasuní. Primera fase: monitoreo de aguas - screening Octubre de 1997. Coca, Ecuador: Laboratorio de Aguas y Suelos P. Miguel Gamboa-Fepp; 1998.

18. San Sebastián M. Informe yana curi impacto de la actividad petrolera en la salud de poblaciones rurales de la Amazonía ecuatoriana. Quito: Cicame \& Abya-Yala; 2000.

19. Ministerio de Medio Ambiente de Ecuador. Informe de inspección ambiental al área de las comunidades Flor de Manduro y Centro Manduro ubicadas en el bloque siete operado por la compañía Oryx. Quito: Ministerio de Medio Ambiente; 1999.

20. Perú, Dirección Regional de Pesquería de Loreto. Monitoreo del impacto post- derrame de petróleo sobre los recursos hidrobiológicos entre San José de Saramuro y Nauta, Río Marañón. Iquitos, Perú: Dirección Regional de Pesquería; 2000.

21. Campbell D, Cox D, Crum J, Foster K, Christie P, Brewster D. Initial effects of the grounding of the tanker Braer on health in Shetland. BMJ. 1993;307: 1251-5.

22. Palinkas LA, Petterson JS, Russell J, Downs MA. Community patterns of psychiatric disorders after the Exxon Valdez oil spill. Am J Psychiatry. 1993; 150(10):1517-23.

23. Lyons RA, Temple MF, Evans D, Fone DL, Palmer SR. Acute health effects of the Sea Empress oil spill. J Epidemiol Community Health. 1999;53(5):306-10.

24. Falaschi $\mathrm{C}$, ed. Informe socio ambiental sobre Loma de la Lata. Available from: http://www.ecoportal.com.ar/articulos/ lomalata.htm Accessed 26 May 2003.

25. Kimerling J. Rights, responsibilities, and realities: environmental protection law in Ecuador's Amazon oil fields. Southwestern J Law Trade Americas. 1995; 2(2):293-384.

26. Unión de Promotores Populares de Salud de la Amazonía Ecuatoriana. Culturas bañadas en petróleo: diagnóstico de salud realizado por promotores. Quito: Abya-Yala; 1993.

27. San Sebastián M, Armstrong M, Stephens $\mathrm{C}$. La salud de mujeres que viven cerca de pozos y estaciones de petróleo en la Amazonía ecuatoriana. [The health of women who live near oil wells and oil production stations in the Amazon region of Ecuador] Rev Panam Salud Publica. 2001;9:375-84.

28. San Sebastián M, Armstrong M, Stephens C. Outcome of pregnancy among women living in the proximity of oil fields in the Amazon basin of Ecuador. Int J Occup Environ Health. 2002;8:312-9.

29. San Sebastián M, Armstrong M, Cordoba JA, Stephens C. Exposures and cancer incidence near oil fields in the Amazon basin of Ecuador. Occup Environ Med 2001;58:517-22.

30. Hurtig AK, San Sebastián M. Geographical differences of cancer incidence in the Amazon basin of Ecuador in relation to residency near oil fields. Int J Epidemiol 2002;31:1021-7.

31. Frente de Defensa de la Amazonía. La Texacontaminación en el Ecuador. Lago Agrio, Ecuador: Frente de Defensa de la Amazonía; 1999.

32. Acción Ecológica. Amazonía por la vida. Available from: http://www.accion ecologica.org/petroleo.htm Accessed 27 May 2003.

33. Instituto Nacional de Estadísticas y Censos del Ecuador. VI censo de población y V de vivienda. Quito: INEC; 2001.

34. Acosta A. El petróleo en el Ecuador: una evaluación crítica del pasado cuarto de siglo. In: Martínez E, ed. El Ecuador post petrolero. Quito: Acción Ecológica; 2000. Pp. 2-19.
35. Terán C. Sucumbios 2000. Lago Agrio, Ecuador: Vicariato de Sucumbíos; 2000.

36. World Bank. Ecuador overview. Available from: http://www.worldbank/ org Accessed 28 May 2003.

37. Centro de Derechos Económicos y Sociales. Apertura 2000 . . . la solución al país? Boletín número 2, marzo. Quito: Centro de Derechos Económicos y Sociales; 2000.

38. Kimerling J. The human face of petroleum: sustainable development in Amazonia? Rev Eur Community Int Environ Law. 2001;10(1):65-81.

39. Raffensperger C, Tickner J. Protecting public health and the environment: implementing the precautionary principle. Washington, D.C.: Island Press; 1999.

40. Centro de Derechos Económicos y Sociales. Una opción para el país: deuda por conservación de la Amazonía. Quito: Centro de Derechos Económicos y Sociales; 2000.

41. Acosta A. ¿Es posible la transición a una economía post petrolera? In: Martínez E, ed. El Ecuador post petrolero. Quito: Acción Ecológica; 2000. Pp. 38-55.

42. British Medical Association. Health and environmental impact assessment: an integrated approach. London: Earthscan; 1998.

43. Korten D. When corporations rule the world. London: Earthscan; 1995.

44. United Nations Environmental Programme. Global environment outlook. Nairobi, Kenya: Earthscan Publications; 1999.

45. Stephens C, Lewin S, Leonardi G, San Sebastián M, Shaw R. Health, sustainability and equity: global trade in the brave new world. Global Change Human Health. 2000;1(1):44-58.

46. Shell. The Shell report 2002. Meeting the energy challenge. Available from: http:// www.shell.com/home/Framework?site Id=shellreport2002-en Accessed 30 May 2003.

47. British Petroleum. Environment and society. Available from: http://www.bp. com/environ_social/index.asp Accessed 30 May 2003

48. Oxy. Social responsibility. Available from: http://www.oxy.com/HTML/ socialrespons.html Accessed 30 May 2003.

49. La Torre López L. ¡Sólo queremos vivir en paz! Experiencias petroleras en territorios indígenas de la Amazonía peruana. Copenhague: Grupo Internacional de Trabajo sobre Asuntos Indígenas; 1998.

50. Oilwatch. Fluye el petróleo, sangra la tierra. Quito: Oilwatch; 1999.

Manuscript received 3 July 2003. Accepted for publication on 17 November 2003. 